\title{
Connecting factor lex loci coindentiae testatoris et heredes hereditarium commodum as a basis for persons' testamentary interests securing in regard to contractual succession
}

\author{
Edvard Pilipson* \\ Rīga Stradinsš University, Latvia
}

\begin{abstract}
Obligation law unstable nature under contractual succession discrete situations forces to find appropriate connecting factor which secures involved persons testamentary interests. Because of this, the aim of this work is to summarize connecting factors, using in testamentary and obligation law and to prove the necessity of a new connecting factor for contractual succession.
\end{abstract}

Key words: connecting factor, contractual succession, obligation law, testamentary interests.

\section{Introduction}

The purpose of this study is to identify the legal aspects of the formation of testamentary interests of the parties to a hereditary relationship under connecting formula lex loci coindentiae testatoris et heredes hereditarium commodum application procedure. To achieve this aim tasks used in this article include the research of main categories, engaged in contractual succession. Method - to conduct the research, interpretation method of legal acts and law interests was used.

\section{Discussion}

Connecting factors which regulate applicable law under succession law and law of obligations (lex personalis, lex rei sitae, lex voluntatis) do not satisfy interests of individuals in regard to contractual succession completely.

Due to this circumstance to secure persons' testamentary interests connecting factor lex loci coincendentiae testatoris et heredes hereditarium commodum was created and elected to analyze through the term "analysis of the interest of the parties to the inheritance agreement".

The term "analysis of the interest of the parties to the inheritance agreement (or, sometimes, contract)" was chosen for the purpose of revealing the topic of the article not by chance - the institution of the inheritance contract is fixed in the national legislation of different states in the formulations so contradictory that depending on the applicable law, this fixing in the situation of searching for applicable law and cross-border execution can lead to ambiguous consequences directly diverging from the interests of the parties to the agreement mortis causa. The theory of interest of the parties in the agreement is quite successfully fixed

\footnotetext{
* Corresponding author: e.pilipsons@privattiesibas.lv
}

(C) The Authors, published by EDP Sciences. This is an Open Access article distributed under the terms of the Creative Commons Attribution License 4.0 (http://creativecommons.org/licenses/by/4.0/). 
in the Restatement Second of Contracts - this code asserts that "legal means of contract law serve to protect at least one of the three interests - probable interest, basic interest, restorative interest" [1]. Given the positive feedback on this document by academic staff [2], it seems that it is with these categories in mind that the interest of the parties to the inheritance agreement will be analyzed. Interest as a legal category has long taken place in the legal science [3] and practice [4] and for this reason will serve as an analysis of contractual succession in general and the inheritance contract in particular.

The law, which is a tool for compromising the interests of the parties, protects the reasonable interests and expedient ways to meet them. Proceeding from this message, the main problem in the situation of the concluded inheritance contract is a compromise between the interests of the parties regulated by the two main spheres of legal regulation of contractual succession - the obligation law and the right of inheritance. According to Kevin Davis the contract is a product of interaction of the document and rules of its designing and execution [5]. The main interests of the parties in inheritance law are: protection of the real and implied will of the testator, protection of public interest, interest in protecting family values. Since the legal nature of inheritance by law and testament is a gratuitous transfer, in fact, the granting of the property of the testator to the heir, the particular interest of the testator consists of proportionately reducing the expenses of the heir in accepting the inheritance. Interesting from the point of view of the law of obligations is a restriction in the interest of the testator to establish additional, not prescribed by law, property rights - the principle of equality of the parties in the contract provides for the impossibility of unilateral withdrawal from the obligations that complicate the situation in this case, the heir or other person engaged in performance of the contract. The interest of the heir in the inadmissibility of depriving him of his property right is directly opposed to the interest of the testator to change or to cancel the testamentary order by a unilateral act that classifies the initial interest in the category of interests governed by the obligation law. The specific interest of the parties in the inheritance agreement is a singular succession. Opposite to universal succession, being according to interpretation by Pierre Legrand historically designed to determine the fate of real, rather than mandatory, rights in the event that something extraordinary happens with the owner of the thing, unforeseen, unavoidable [6]. The basis for the emergence of this institution is the concept of successor as a continuer of the personality of the predecessor. Undoubtedly, the universal succession as a legal interest in the situation of the inheritance contract undermines the principle of equality of parties in the contract because of uncertainty the heir is not informed about the liabilities of the hereditary mass and other possible obligations, conditioned by the fiduciary nature of contractual succession. In turn, arising from the interest of the testator in the reduction of the heir's expenses and corresponding with the similar interest of the heir, this interest is represented as the main interest in both the inheritance contract in particular and in contractual succession, in general - this interest fits into the concept of both probable and basic interest.

The heir's interest in informing him about the debts and encumbrances of the hereditary mass should also be included in the category of basic interest. This requirement comes from the current concept of contractual succession. The introduction of this interest will help to give the contractual succession a property of the legal nature of lex specialis - normative acts regulating inheritance by law and will not contain the obligation to inform the heir of debts and other encumbrances of the hereditary mass, the possibility of refusing to accept the inheritance in the situation of inheritance by law and testament gives the obligation of informing an optional character. It is envisaged that in the situation of inheritance by law and will, the lack of information will not affect the essential interests of the heir. Contractual succession has a different legal nature, and the lack of proper information can lead to a serious violation of the legitimate interests of the heir. Moreover, according to Stein (Stein), 
this principle opens up the true structure of the right [7], and according to the author of the study, will fully disclose the principle of equality of parties in the treaty. The construction of contractual succession should not contain amorphous positions - the essential constituent parts of the inheritance contract and the rules of law that establish interest in informing the heir should not contain ambiguity. Uncertainty in this interest should not occur. Of course, at the disposal of the heir there are remedies mediating restorative interest, but at the current stage of the existence of contractual succession, these funds are not individually identified the issue of the substantive component and the procedural and legal form of the claim and the issues arising from these circumstances, jurisdiction, competent court, other issues. In this connection, the apparent impossibility of realizing a recovery interest is seen, both by the testator and the heir. According to the provisions of Roman private law, the hereditary claim has a legal nature in rem, whereas a claim from a liability law has a legal nature in personam. The typifying of a possible suit from contractual succession is currently absent, in turn, the mechanical linking of the categories indicated above will not lead to the realization of a recovery interest - the determination of the claim as the person's right to exercise the demand [8] compels to eliminate the dichotomy existing between the requirement of a hereditary character and the requirement of a binding nature. The number of claims in Roman private law has always been limited [9] and the typifying of claims occurred through the designation of the types of major institutions. Taking into account the basic concept of contractual succession, the claim design can take the form of actions ficticiae [10] with a dichotomy for a negative fiction and a positive fiction in the understanding of Best [11] and having as the main constructing element of the action injusconceptae a body that applies the law to an authority or a person may apply an undue path to the realization of the interests of the parties to the legal relationship, thereby creating a dispute over the supremacy of law [12].

The binding of the legitimate interests of the parties in the situation with a new legal entity, which is contractual succession, is undoubtedly also in the sphere of the method of legal thinking and the methodology of handling legal material.

Adhering to the concept of Jerome N. Frank [13] and using categories expressed by the concepts "thinking about the rule (law), thinking about the decision and thinking about the order and form" for the purpose of a fair resolution of the interests of the parties to a treaty inheritance it seems reasonable to synthesize into the concept of satisfying the due. In this regard, the question of what is due in contractual succession is appropriate. The legal doctrine concerning contracts and inheritance speaks rather ambiguously: Gustav Radbruch argues that legal freedom leads to de facto inequality of the parties in the social plan and the task of the law is to restore freedom of contract by limiting legal freedom [14]. The thesis on the actual inequality of the parties in the social plan, of course, found its confirmation - the heir under the contract, the testator has all the rights to write off virtually all of his property, this right is limited only by the mandatory share (German Civil Code, Paragraph 2303, the Swiss Civil Code, Article 471, Law of Succession Act (Estonia), Article 104, Austrian Civil Code, Paragraph 764) and an additional mandatory share (German Civil Code, Paragraph 2305), by other institutions. However, the mandatory share is a value expression of property that is subject to dynamic fluctuations. Also, according to the provisions of normative acts, the value of property is divided a simple, specific, reasonable personal aspirations (Civil Law, Section 870), consumer (utility, Gebrauchswert) (German Civil Code, Paragraph 555b). Also the value of the property is secured other terminology of a legal and non-legal nature, in particular interpreting (Jessica L. Roberts) the cost can be based on the principle of private attachments [15] (personal belongings-Jessica L. Roberts, 2015). Due to the evaluation nature of the terms mentioned above, the right to equality of interests of the heir under the contract and heirs, family members of the testator is violated. With respect to inheritance Gustav Radbruch argues that it should serve and provide the splendor of the family 
(splendor familiae) [16]. The legal possibility of the testator to enter into relations on contractual succession with any person who has passive testament factio and to alienate by means of this method the property actually acquired by the whole family is a fairly vivid example of a violation of the interests of the testator's family. The right to an obligatory share in hereditary property of undefended heirs in this case does not actually contribute to the creation of a balance of interests of the heir under the contract, unbending heirs, and heirs on other grounds.

The main interest of the testator in the appointment of the heir under the contract is that the heir under the contract will provide the testator with care and other obligations that are in accordance with the treaty and mandatory norms. However, paradoxically, in this circumstance there is a fundamental violation of the legitimate interests of the heir-family members of the testator. By virtue of regulations of a number of normative acts, family members have obligations on mutual care for each other (Civil Law, Section 84, German Civil Code, Paragraphs 1356-1360a, Family Law Act (Estonia) Paragraphs 15-19). And the opposition of the family members of the testator to the heir under the contract does not facilitate the realization of the interests of the parties either in hereditary or in the obligation law. The possible equalization of interests, both parties to contractual succession, and third parties will undoubtedly be facilitated by the introduction into the inheritance agreement of categories called "the initial value of inherited property" (property primary value) [17] and "the final value of inherited property" (property final value) [18]. Since inheritance under the contract is a continuing relationship, the introduction of these categories motivates the heir under the contract to make due efforts to comply with the value regime of its efforts to execution of the inheritance agreement, and will promote the observance of hereditary rights of heirs not included in the inheritance agreement - the exit of the value of the property beyond the upper limits indicated by the term "final value of inherited property" harmonizes the lawful regime of ensuring the interests of the testator and contractual regime mediated by the inheritance contract in respect of both heir under the contract, and heirs on other grounds. Moreover, the introduction of the above categories in the inheritance agreement harmonizes the intellectual process of creating a single will and its external expression of the heir (heirs) appointed by the contract and heirs on other grounds, mediating them in a possible agreement.

Legitimate interests have the following features: promote the development and improvement of social ties, fixing a certain combination of personal and public interests, bear a certain regulatory burden, acting in suigeneris legal regulation, act as independent elements of the legal status of the individual, are guaranteed by the state and supranational structures in the form of norms of material and conflict of laws. It seems that the main function of the interests of the parties in contractual succession is to become a concretization. The lack of specification of legitimate interest is due to the fact that it does not correspond with a clear legal obligation of counterparties, in contrast to subjective rights that cannot exist without corresponding responsibilities. This can be seen on the example of the correction of spheres of legal regulation (specifically - family law) when correlated with the inheritance contract. According to the provisions of the peremptory norms of family law, one of the main duties of family members is caring for each other, creating and providing mutual funds of property and non-property for the advancement of the family. A similar provision is enshrined in mandatory rules regarding the right of inheritance. The existing situation is a basic interest, which is the basis of the desire to implement authorized actions. In this case, the legal norm gives the person a new power, increases his power in the exercise of his interests [19]. Since the interest of the parties is a simple permissiveness, without prejudice, its legal possibilities are expressed in the request, but not in mutual obligations. Elements of content of legitimate interest are nature of aspirations, rather than firmly guaranteed opportunities. The relationship 
of legitimate interest to the good, as well as their protection, is more remote than that observed in subjective law. Additional difficulties arise in the situation of the need to translate the probable and restorative interests in the reference one. Probable and basic interest in the inheritance agreement is objectified by the concept of hereditatis futurae. In this case, it seems reasonable to draw a conclusion that two employees of interest do not contribute to the emergence of a core interest that is leading to the formation of the mode of action of empowered persons and, what is most important in this case, do not contribute to a correct understanding of the rules of law in the formation of the subject matter of the inheritance contract. It seems that the quantitative criterion (in this case, probable and basic interests) is that in the legitimate interests of the parties to an inheritance contract, connections are mediated that the right did not have time to translate into correct, relevant contemporary situations, subject to rapidly developing social relations, creating a space, which cannot be typified in connection with his personality, rarity and irregular randomness, in other words, the impossibility to mediate interests in the depth of the legal relationship.

Inheritance contract is a fiduciary legal transaction within the meaning of Kaspar Balodis (Kaspars Balodis) [20] and Dietrich Andrey Lober (Dītrihs Andrejs Lēbers, Dietrich André Loeber) [21] which, by virtue of the concept hereditatis futurae is of aleatory character. It is also possible to argue that the contractual succession as a whole according to the legal nature of the approached and in some cases can be equated to the relations on the purchase agreement, the purchase in installments (Civil Law, Sections 2069-2071), Civil Code of the Austria, Paragraphs 1053-1089, French Civil Code, Article 1582, Sale of Goods Act 1979 (Sale of Goods Act 1979, 1979 Chapter 54), Sale of Goods Act 1893 (Sale of Goods Act 1893, 1893 Chapter 71). Due to this circumstance, a possible means of linking the interests of the parties will be the requirement in the inheritance contract to provide the promised (stipulatio) with the introduction of the main or collateral contract (side agreement-George Cohen, 2006) of the relevant substantive and procedural legal imperatives - it seems that this step will equalize the likely, basic and restorative interests of both the parties to the inheritance agreement and third parties. This condition can be formulated on the basis of paragraph 443 of the German Civil Code, which prescribes to the seller (in the situation of the inheritance agreement) the obligation to provide information in the form of a guarantee declaration (Garantieerklärung) [22]. This innovation give for the subject matter essential parts of contractual succession the features of certainty and conformity of the concept persona legalis intentiones.

It appears that the most significant difficulty in identifying the true legitimate interests and their co-respect mediated by hereditary and obligation law factors in a situation of succession by contract will be the agreement concluded in favor of a third party. The third party in relation to the testator and at the same time in relation to the heir to the donor is in understanding the principles of the law of obligations - donation of the object and property rights to it actually happening on the rules of the agreement or unilateral (depending on the qualifications of the applicable law), transactions [23]. It seems reasonable to argue that the transaction should be classified as a donation. In this form of hereditary transmission there is a dilemma about the rights of the direction and as a result, there is a risk of the object of uncertainty (uncertainty of object - Roger Kerridge, 2007) described in academic writings [24] and subsequently, to the loss of the gift [25]. Analysis of the dynamic aspect of the regulatory impact on the folding relationship must cut the negative trends and promote the optimization and, in accordance with the objectives of the study of hereditary disposition in favour of a third party to carry out lawful co-respect, linking legal interests as the heir and the testator and the third party. In the situation prevailing on the matter cannot be seen integrity hereditary situation - a third party may be in a legal relationship, both with the testator and the heir. In the presence of the legal relationship is possible the competition rules 
of inheritance law and law of obligations. In this situation, the reference interest [26] can go into the category of the recovery of interest, which in this situation may fix in the term "right to claim" by providing this right to a third party. Legal nature of the requirement in this case is not defined - whether it will be in the nature of the requirements of law or the inheritance of the law of obligations is not clear - the concept of the lex specialis in relation to a treaty inheritance is not developed, it seems omission - that the lex specialis should be the basis of the right of claim [27]. In addition, competition is possible within the legal norms liability law - the right of the closest contract is subject to a different order of ex ante execution. Constructing this legal relationship is reasonable to conclude from the donee and the heir to the individual contract - the contract of donation mortis causa and the contract rejection of inheritance $\mathrm{c}$ donee and heir, respectively. At the present moment the inheritance of the contract to a third party is very similar to a conflict of interest as the primary reason of this relationship within the legal phenomenon. Without unduly limiting the activities mentioned above (restriction of the right of a third party requirements the testator) subjective right can sometimes turn into a legitimate interest, while losing a significant legal effect, other legal options - interests of the parties in a contractual succession should be closely linked with the principle of effectiveness in law enforcement, the requirement of which is that within the normal range given the opportunity to choose the most effective solution that fully and correctly reflects the idea of law, the meaning of the law, the right of the goal of the law regulation, the circumstances of the particular case. Inheritance under the contract to a third party who is not a member of the family of the testator, in fact, a donation mortis causa, Affecting the subject structure of relationship, it is difficult to clarify the relation of the applicable law - the testator opposed indefinite face in understanding Hohfild, quoted Thomas Merrill and Henry Smith [28]. Implementing the requirement of expediency, in this case, the participants of the process of succession agreement does, first of all, an act of satisfaction or protection of certain legitimate interests. This means that if the norm establishes the feasibility of the rule of law and therefore suitable enforcement (executive processes of an ex ante and an ex the post, then the focus should be primarily on the implementation of legitimate interests. However, the entry into the process of implementing a third party with an uncertain legal status creates a conflict of interest, in a situation when a conflict of interest can be defined as a situation where a person or organization appear simultaneously in several faces, goals do not coincide or conflict with each other. In this case, the pertinent question of the causes of performance interests. This issue should be closely linked to the implementation of the principle. Implementing the principle of expediency of a third party is not burdened with specific legal obligations in favour of the testator. Furthermore, under the existing circumstances Affairs of a third party law have the right to choose from a few necessary (choice between individual legal status of the donee or heir) one that will exactly match the specific life event and determined to apply the rules of law in respect of the legal regulation of family, inheritance and the law of obligations - Implementation of interests through the rule of law is not possible in cases where the latter affect the processes, which strongly expressed the spontaneous moment [29]. Term "spontaneous moment" refers to the uncertainty of the individual legal status of the third party and the potential conflict of norms of obligation and inheritance law. The objective of the parties, as well, and the law enforcer in this situation to narrow the scope of the applicable law in respect of the subject composition and determine the priority sphere of legal regulation, thereby eliminating misconceptions about the person with whom the transaction is, or persons associated with the transaction. Undoubtedly, the interests of the parties, as well as and third parties in relation to the inheritance of the contract within the scope of legal regulation and should be protected by legal means, however, the character and the nature of these funds to date is not set and when using traditional means possible collisions among law and qualifications. 
The content of the legal relationship of the parties is made up of two elements: the desire to use a particular social benefit and to address, where appropriate, for the wired to the competent authorities of the state. Lack of object characteristics, the dichotomy of his subject between inheritance law and law of obligations, in some cases, opposition to the imperatives of family law prevents the mentioned above elements emerge organically legal matter and purpose of the law - a prominent researcher interest in the right to Philipp Heck pointed out that "we do not work to obtain some knowledge, but in order to serve life" [30]. In the case of contract inheritance contract to a third party exists the risk of appearance of probabilistic interest factors, which, unlike a possible interest factors possesses with unpredictable nature, characterized by the lack of information on the occurrence of a legal facts, the term of the events relevant for the rights, power and way of influencing events in substantive law and that seems mainly probabilistic interest does not describe and establish the degree of corruption and interaction of the material interests of persons [31]. Due to these circumstances need to submit, that probabilistic interest not can serve as a category for the choice of the applicable law.

Generalization approval Glenville (Glanvill), quoted by Pluknett (Plucknett), that right there is the effect, inter alia, as a way to influence legal thinking and method of treatment of legal materials [32] makes it possible to correctly link the mutual interest of treaty parties to inheritance in a situation of succession of the contract concluded by the introduction of evaluation standards in the contractual succession in order to equalize, compensate and adequate testamentary interests of the parties.

\section{Results}

Existing situation, when the instruments of contractual succession are regulated by the conflict binding, mentioned above (lex personalis, lex rei sitae) does not meet the requirements of legal regulation regarding to future legacy factor.

The interests of the parties to the legal relationship require a more flexible approach. This approach introduces only by hereditarium commodum collision factor. It is this factor that together with factor loci must settle the applicable law - factor loci based on the fulfillment of obligations, delineates the performance of hereditary obligations from obligations of a different legal nature.

\section{Conclusions}

This introduction is also justified by the fact that the legal regulation of the afore mentioned spheres of legal regulation exists in contractual succession in undetermined form.

Also, due to the fact that contractual succession exists in the law as a legal phenomenon with disordered nature under understanding of Ronald J. Allen and Ross M. Rosenberg [33]. Hereditarium commodum category will form the basis of correct application of both national and foreign material (substantive) law - in this case it is not only the definition of the applicable law, but also on the impact exerted on the corresponding social relations (interests) which mediated by contractual succession. In turn, the question of the functional filling of the formula lex loci coindentiae testatoris et heredes hereditarium commodum (probability, basic and restorative interest procuring) be placed not only in theory but also in practice legislator, bringing to the forefront of the protection of the interests of persons involved in contractual succession, gives to a contractual succession regulatory and institutional character. 


\section{References}

[1] M.A. Eisenberg, Mich. Law Rev., 560 (2006)

[2] A.T. von Mehren, Cornell Law Rev. 67, 631-639 (1982); H. Dubroff, St. John Law Rev. 80, 559-620 (2012)

[3] H.D. Laube, Cornell Law Rev. 34(3), 291-302 (1949); J.C. Verhelle, Loyola Univ. Chicago (1958)

[4] Supreme Court of the Republic of Latvia. Decision in case A 412021209.

[5] K.E. Davies, New York Univ. Law Rev. 88, 89 (2013)

[6] P. Legrand, Harvard Int. Law J. 47(2), 517 (2006)

[7] S. Zorzetto. Eunomía. Revista en Cultura de la Legalidad, 3, 62 (2012)

[8] D.44.7.51; I.4.6.pr.

[9] W.W. Buckland, The Main Institutions of the Roman Private Law (Cambridge: Cambridge University Press, 1931)

[10] A. Berger, A Dictionary of Roman Encyclopedic Law, edited by Clark, 7th edn. (The Lawbook Exchange ltd, 2004), p. 346

[11] W.M. Best, A Treatise of Presumption of Law and Fact, with the Theory and Rules of Presumptive of Circumstantial Proof in Criminal Cases (T. and J.W. Johnson, Philadelphia, 1845), p. 38

[12] J.T. Abdy, Bryan Walker. The Commentaries of Gaius and rules of Ulpian, edited by Clark, 3rd edn. (The Lawbook Exchange ltd, 2005), p. 486

[13] J.N. Frank, Syracuse Law Rev. 10, 9-25 (1949)

[14] G. Radbruch, Oxford J. Legal Stud. 26(1), 1-11 (2006)

[15] J.L. Roberts, Theories of Genetic the Ownership. The Pertie-Flom Centre for Health Law the Policy ... at the Harvard Law School // http: //petrieflom. law . harvard. edu/assets/publications/Roberts_ Genetic_ Ownership_ Draft.pdf (27. 06. 2018)

[16] Ibid, p. 175

[17] J. Nedlesky, Laws relations: a rational theory of Self, Autonomy, and Law (Oxford University Press, New York, 2011), p. 255

[18] L. Friedman, Touro Law Rev. 19(4), 617 (2014)

[19] F. Cafaggi, A comparative analysis of transnational private regulation: legitimacy, quality, effectiveness and enforcement. Report Comparative, http://www.eesc. europa.eu/resources/docs/a-comparative-analysis-of-transnationalprivate-regulation-fcafaggi_ 12062014.pdf (15.06.2018)

[20] K. Balodis, Likumsuntiesības. 9, 270-271 (2005)

[21] D.A. Lēbers, Tieslietu MinistrijasVēstnesis. 9, 222-223 (1933)

[22] German Civil Code. Section 443. Guarantee. (1) Where the seller, the producer or some other third party enters into obligation, in addition to his statutory liability for defects, by way of making a declaration or in relevant advertising that was available prior to the purchase agreement being concluded or at the ITS Conclusion of time, such being of the Obligation in Particular to reimburse the purchase price, to the Exchange Thing, to repair or to the provide IT services in the this context the Thing Should not the not exhibit the quality or not fulfil other requirements than those concerning its freedom from defects, in each case as described in the declaration or in the relevant advertisement (guarantee), the buyer shall be entitled, in the case of a guarantee having been given, and notwithstanding his statutory claims, to the rights under the guarantee in relation to the person who has given the guarantee (guarantor). (2) To the extent that the guarantor gives a guarantee as to the thing having a specified quality for a specified period (guarantee of durability), the presumption will be that a material defect which 
appears during the guarantee period triggers the rights under the guarantee. German Civil Code, Federal Law Gazette I p. 3719. With amendments

[23] W. Snijders, The Civil Codes of the Russian Federation and the Netherlands: Similarities and Contrasts, Private and Civil Law in the Russian Federation, edited by W. Simons (Martinus Nijh off Publishers, Leiden, 2009), p. 33

[24] English Private Law, Failure of Gifts by Will or of Interests on Intestacy, edited by prof. Andrew Burrows, 2nd edn. (Oxford: Oxford University Press, 2007), p. 603

[25] Ibid, p. 460

[26] In this case: the interest of the testator to donate property

[27] Contemporary International Law Issues: Opportunities at a time of momentious Change. Proceeding of the Second Joint Conference held in the Hague, the Netherlands, July 22-24, 1993 - (Boston: MartinusNijhoff Publishers, 1994), p. 8

[28] T.W. Merrill, H.E. Smith, Columbia Law Rev. 101, 774-799 (2001)

[29] F. De Vecchi, Edith Stein's Social Ontology of the State, the Law and Social Acts. An Eidetic Approach, Early Phenomenology, edited by D. Morgan and R.K.B. Parker, (Zeta Books, 2015), p. 312

[30] H. Philippe, Begriffsbilding und Interessenjurisprudenz (Mohr, Tübingen, 1932), $228 \mathrm{~S}$

[31] K. Bilz, J. Nadler, Law, Moral Attitudes, and Behavioral Change (The Oxford Handbook of Behavioral Economics and the Law, 2014), pp. 241-269

[32] T.F.T. Plucknett, Concise history of the common law, 5th edn. (Butterworths, London, 1956), p. 256

[33] R.J. Allen, M. Ross, Chicago-Kent Law Review 77, 686 (2002)

[34] Restatement Second of Contracts, The American Law Institute, 1981. With amendments

[35] German Civil Code, BGB1. I S. 3719. With amendments

[36] The Swiss Civil Code, BB1 1904 IV 1, 1907 VI 367. With amendments

[37] Law of Succession Act (Estonia), RT I 2008, 7, 52. With amendments

[38] Civil Code of the Austria, JGS Nr. 946/1811. With amendments

[39] Civil Law, ValdībasVēstnesis, 41, 20.02.1937. With amendments

[40] French Civil Code, Journal officiel de la République française, 21.05.2018. With amendments

[41] Sale of Goods Act 1979, 1979 Chapter 54. With amendments

[42] Sale of Goods Act 1893, 1893 Chapter 71. With amendments

[43] Family Law Act (Estonia), RT I 2009, 60, 395. With amendments 